\title{
Heat shock protein (HSP 72) expression in patients undergoing cardiac operations
}

The major mammalian stress-inducible protein, heat shock protein 72, protects cells from certain stresses and rapidly accumulates in cells after ischemia. Heat shock protein $\mathbf{7 2}$ is rapidly synthesized in the myocardium of various species in response to ischemia, but it has not been investigated in human heart. To determine if heat shock protein 72 accumulated in the ischemic myocardium of patients undergoing cardiac operations, we obtained sequential right atrial biopsy specimens from 12 patients undergoing repair at three intervals: before bypass, after reperfusion, and after bypass. Immunoblot analysis for heat shock protein 72 demonstrated a high expression in the human heart compared with other mammalian hearts, $p($ Binomial $)=0.01$. Compared with before bypass, heat shock protein 72 contents after reperfusion and after bypass were $98.2 \% \pm 8.9 \%, p$ (signed-rank) $=$ 0.65 , and $87.6 \% \pm 17.1 \%, p$ (signed-rank) $=0.28$, respectively. Although heat shock protein 72 concentration was unchanged in hearts after reperfusion and after bypass, the initial prebypass level of heat shock protein 72 was high. The high heat shock protein 72 level detected in human hearts may reflect preoperative disease and drug therapy, or inherently high levels may be usual in the human myocardium. These findings indicate that the myocardium of patients undergoing cardiac operations contains relatively high concentrations of heat shock protein 72 , which are not increased during the surgical procedure. (J THORAC CARDIOvaSC SURG 1995;109:370-6)

Lynn B. McGrath, MD, Marius Locke, PhD, Michael Cane, MD, Chao Chen, $\mathrm{PhD}$, and C. David Ianuzzo, $\mathrm{PhD}$, Browns Mills, N.J.

$\mathrm{T}_{\mathrm{H}}$ he risk for hospital death after cardiac surgery remains significant and is largely due to lack of scientific knowledge regarding optimal methods to preserve myocardial function after cardiac ischemia induced by periods of aortic crossclamping. ${ }^{1}$ Modification of the myocardial response to ischemia during cardiac operations, to limit myocardial ischemia-reperfusion injury, has focused on composition of the cardioplegic solution, ${ }^{2}$ methods of delivery of the solution, ${ }^{3}$ provision of external substrates, ${ }^{4}$ temperature

From the Department of Surgery, Deborah Heart and Lung Center and Deborah Research Institute, Browns Mills, N.J.

Supported in part by the Max Baer Heart Fund.

Received for publication March 10, 1994.

Accepted for publication June 20, 1994.

Address for reprints: Lynn B. McGrath, MD, Chairman, Department of Surgery, Deborah Heart and Lung Center, 200 Trent Rd., Browns Mills, NJ 08015.

Copyright $@ 1995$ by Mosby-Year Book, Inc.

$0022-5223 / 95 \$ 3.00+0 \quad \mathbf{1 2} / \mathbf{1} / \mathbf{5 8 8 2 4}$ manipulation, ${ }^{5}$ and the induction of diastolic arrest ${ }^{6}$ as strategies to preserve myocardial metabolism.

More recently, it has been discovered that the heart has its own systems of protection against ischemia-reperfusion injury. ${ }^{7}$ Two potential methods of reducing myocardial injury are ischemic preconditioning and heat shock or stress protein induction. These two modalities have been shown to induce the major mammalian stress-inducible protein, heat shock protein 72 (HSP 72), and both have potential to ameliorate the effects of myocardial ischemia. ${ }^{8}$ Heat shock or stress proteins, HSP 72 in particular, may have a pivotal role as a cytoprotective protein in this process, yet the extent to which HSP 72 is present in human cardiocytes has remained unknown. ${ }^{9}$ Thus, to determine if HSP 72 was detectable and/or accumulated in the stressed human myocardium, we examined HSP 72 content in the right atria of patients at three intervals (before bypass, after reperfusion, and after bypass) during cardiac operations. 
Table I. Clinical and demographic variables for the 12 patients

\begin{tabular}{ccclccl}
\hline Patient & Age $(y r)$ & Gender & \multicolumn{1}{c}{ Diagnosis } & AXC (min) & $C P B($ min $)$ & \multicolumn{1}{c}{ Procedure } \\
\hline A & 53.7 & M & CAD & 13 & 25 & CABG \\
B & 47.9 & F & MR, MS & 39 & 61 & MVR \\
C & 4 & M & VSD, PS, subvalvular AS & 15 & 44 & $\begin{array}{c}\text { Resection of subvalvular AS, } \\
\text { infundibular resection }\end{array}$ \\
D & 70.6 & M & CAD & 30 & 70 & CABG \\
E & 52.4 & M & CAD & 31 & 68 & CABG \\
F & 24.8 & F & AS & 30 & 55 & Resection of subvalvular AS, AVR \\
G & 49.4 & F & Partial AV canal & 11 & 31 & ASD repair \\
H & 65 & M & CAD & 19 & 45 & CABG \\
I & 45 & M & CAD & 25 & 51 & CABG \\
J & 19.6 & M & Complete AV canal & 27 & 58 & Closure of mitral cleft VSD repair \\
K & 9.1 & F & VSD, PS & 12 & 44 & Infundibular and VSD repair \\
L & 16.1 & F & ASD & 5 & 22 & ASD repair \\
\hline
\end{tabular}

$A S$, Aortic valve stenosis; $A S D$, atrial septal defect; $A V$, atrioventricular; $A V R$, aortic valve replacement; $A X C$, aortic crossclamp time; $C A B G$, coronary artery bypass grafting; $C A D$, coronary artery disease; $C P B$, cardiopulmonary bypass time; $M R$, mitral valve regurgitation; $M S$, mitral valve stenosis; $M V R$, mitral valve replacement; $P S$, pulmonary stenosis; VSD, ventricular septal defect.

\section{Methods}

Patients. Using a protocol approved by the Institutional Review Board at Deborah Heart and Lung Center, Browns Mills, New Jersey, we obtained informed consent from all patients before they were included in the study. In March 1993, 12 patients underwent open intracardiac repair for congenital, acquired, or coronary artery disease, by a single surgeon (L.B.M.) (Table I). Cardiopulmonary bypass was established with a crystalloid-albumin prime at a flow rate of $2.2 \mathrm{~L} / \mathrm{min}$ per square meter up to a maximum flow rate of $4 \mathrm{~L} / \mathrm{min}$. The patients were cooled to $28^{\circ} \mathrm{C}$ (nasopharyngeal), at which point the flow rate was reduced to $1.6 \mathrm{~L} / \mathrm{min}$ per square meter. In addition to moderate systemic hypothermia, the methods of myocardial protection used included a single period of aortic crossclamping, with myocardial arrest induced by antegrade infusion of cold high potassium $(60 \mathrm{mEq} / \mathrm{L})$ blood cardioplegic solution, with a $2: 1$ blood/crystalloid ratio, at a rate of $300 \mathrm{ml} / \mathrm{min}$ per square meter, until the septal temperature reached $12^{\circ} \mathrm{C}$. A single dose of cardioplegic solution was administered in each case. Topical cold saline solution was also applied.

Three sequential biopsies were performed of the right atrial free wall, from separate sites. The first biopsy specimen was obtained immediately after the pericardium was opened, after the administration of heparin, and before any surgical manipulation of the heart. The second biopsy specimen was obtained after reperfusion, 5 minutes after removal of the aortic crossclamp. The third biopsy was performed 15 minutes after the patient was weaned from cardiopulmonary bypass. Each biopsy sample was divided into three pieces to analyze for tissue HSP 72 content, plus glycogen and lactate concentrations. The specimens were frozen in liquid nitrogen and stored at $-70^{\circ} \mathrm{C}$ until analyzed. Frozen muscle samples were homogenized in 20 volumes of sodium chloride, $600 \mathrm{mmol} / \mathrm{L}$, and tris (hydroxymethyl) aminomethane (Tris), 15 $\mathrm{mmol} / \mathrm{L}$; $\mathrm{pH} 7.5$; protein concentrations were determined by the technique described by Lowry and associates, ${ }^{10}$ with bovine serum albumin used as a standard.
Lymphocyte labeling. Human lymphocytes were subjected to heat shock to determine if HSP 72 is an inducible protein in man. A $10 \mathrm{ml}$ sample of whole blood was obtained from normal individuals. Blood samples were diluted 1:1 with minimal essential media minus methionine (Grand Island Biological Companies, Grand Island, N.Y.), supplemented with heparin, $2 \mu \mathrm{l} / \mathrm{ml}(1000 \mathrm{U} / \mathrm{ml}$; Elkins-Sinn, Inc., Cherry Hill, N.J.), and placed in T25 culture flasks with $10 \mu \mathrm{Ci}$ of $\mathrm{L}^{-35}\left[{ }^{35} \mathrm{~S}\right]-$ methionine (1200 $\mathrm{Ci} / \mathrm{mmol} / \mathrm{L}$; New England Nuclear, Boston, Mass.). The flasks were incubated for 3 hours at $37^{\circ} \mathrm{C}$ or at $45^{\circ} \mathrm{C}$ for 30 minutes and $37^{\circ} \mathrm{C}$ at 2.5 hours (heat shock). Lymphocytes were isolated by placing samples over a $3.5 \mathrm{ml}$ Ficoll-Paque solution (Pharmacia Fine Chemicals, Piscataway, N.J.) and centrifuging them for 30 minutes at 1300 rpm in a clinical centrifuge. Lymphocytes were washed in phosphate-buffered saline solution. Cells were lysed in urea, $9 \mathrm{~mol} / \mathrm{L}$, phenylmethylsufonylfluoride, $1 \mathrm{mmol} / \mathrm{L}$, and $5 \% \mathrm{~B}$-mercaptoethanol and stored at $-70^{\circ} \mathrm{C}$ before electrophoretic analysis.

Radioactivity determination. Incorporation of $\left[{ }^{35} \mathrm{~S}\right]-$ methionine was determined by precipitating an aliquot of the sample with cold $\left(4^{\circ} \mathrm{C}\right) 20 \%$ trichloroacetic acid for 30 minutes. Samples were pelleted by centrifugation at 14,000 rpm for 3 minutes in an Eppendorf microcentrifuge (Brinkman Instruments, Inc., Westbury, N.Y.), washed with ether, repelleted, and dried in a desiccator. Dried pellets were resuspended in $80 \mathrm{mmol} / \mathrm{L}$ Tris-HCl base ( $\mathrm{pH}$ 6.8), 2\% sodium dodecyl sulfate (SDS), 5\% B-mercaptoethanol, and $20 \%$ glycerol, and aliquots were added to a Bio-Safe II cocktail (Research Products International, Mt. Prospect, Ill.). Radioactivity of $\left[{ }^{35} \mathrm{~S}\right]-$ methionine was measured with a Beckman LS-7800 liquid scintillation counter (Beckman Instruments, Inc., Fullerton, Calif.).

Polyacrylamide gel electrophoresis. One-dimensional SDS polyacrylamide gel electrophoresis (PAGE) was performed according to the method described by Laemmli, ${ }^{11}$ except that the separating gels (both $0.15 \times 5 \mathrm{~cm}$ and $0.3 \times 12 \mathrm{~cm}$ ) consisted of a $3 \%$ to $15 \%$ polyacrylamide 

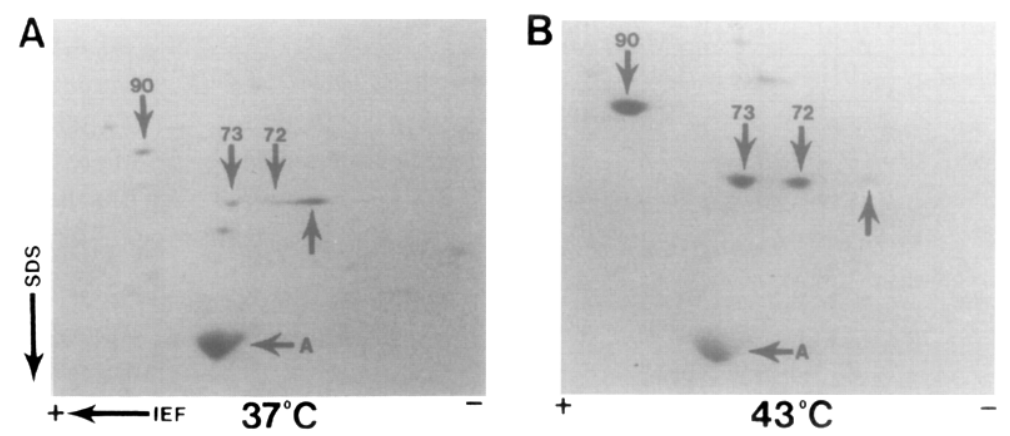

Fig. 1. Fluorographic analyses of IEF/SDS-PAGE separated proteins from human lymphocytes labeled with $\left[{ }^{35} \mathrm{~S}\right]$-methionine at either $37^{\circ} \mathrm{C}$ (control, A) or $43^{\circ} \mathrm{C}$ (heat shock, B). Stress proteins (HSP 72, HSC 73 , and HSP 90) are indicated by downward arrows. Actin $(A)$ and a $70 \mathrm{kDa}$ nonshock stress protein (upward arrow) whose synthesis decreased after heat shock are also included. Gels were processed as outlined in Methods. $S D S$, Sodium dodecyl sulfate; $I E F$, isoelectric focus.

gradient. Two-dimensional (IEF/SDS PAGE) separation of proteins followed the technique of O'Farrell ${ }^{12}$ with minor modifications. The first dimension contained $60 \%$ $\mathrm{pH} 5$ to 8 and $40 \% \mathrm{pH} 3.5$ to 10 ampholytes in the isoelectric focusing gels, and the second dimension consisted of a $3 \%$ to $15 \%$ polyacrylamide separating gel $(0.3 \times 12 \mathrm{~cm})$ overlaid with a $3 \%$ stacking gel. Gels were stained with $0.5 \%$ Coomassie brilliant blue $\mathrm{G}$ in $50 \%$ methanol and $10 \%$ glacial acetic acid; they were destained in $50 \%$ methanol containing $10 \%$ glacial acetic acid. Where appropriate, low-molecular-weight standard proteins (Pharmacia Fine Chemicals, Uppsala, Sweden) were co-electrophoresed. Markers used were phosphorylase-b, 94,000; albumin, 67,000; ovalbumin, 43,000; carbonic anhydrase, 30,000; trypsin inhibitor, 20,100; and a lactalbumin, 14,400 .

Protein transfer and immunoblotting. After electrophoretic separation, proteins were transferred to nitrocellulose membranes $(0.22 \mu \mathrm{m}$ thickness; Bio-Rad Laboratories, Richmond, Calif.) as described by Tobin, Staehelin, and Gordon, ${ }^{13}$ using the Bio-Rad miniprotein II gel transfer system. In brief, gels were equilibrated in transfer buffer (glycine, $192 \mathrm{mmol} / \mathrm{L}$; Tris-Cl, $25 \mathrm{mmol} / \mathrm{L}$ [pH 8.3]; $0.1 \%$ SDS; and $20 \%$ methanol) for 5 minutes and placed into a sandwich consisting of a Scotchguard pad, two pieces of filter paper $(3 \mathrm{~mm}$, Whatman, Inc., Clifton, N.J.), nitrocellulose membrane, the gel, two more pieces of filter paper, and a second Scotchguard pad. All sandwich components were soaked in transfer buffer before assembly. The sandwich and an ice pack were placed in the transblot system and proteins were transferred to the nitrocellulose membrane at a constant voltage of 30 volts for 6 hours, with the ice pack changed at 3 hours. After protein transfer, the nitrocellulose membrane was blocked with $5 \%$ non-fat dry milk powder in Tris-buffered saline (TBS; $\mathrm{NaCl} 500 \mathrm{mmol} / \mathrm{L}$, Tris-Cl $20 \mathrm{mmol} / \mathrm{L}, \mathrm{pH} 7.5$ ) for 2 hours. Blots were washed twice ( 5 minutes each) in TTBS (TBS plus $0.05 \%$ Tween-20) and incubated with an anti-HSP 72 monoclonal antibody (Amersham Corp., Arlington Heights, Ill., RPN.1197) in TTBS with $2 \%$ non-fat dry milk powder for 12 hours at $25^{\circ} \mathrm{C}$. After two washes ( 5 minutes each) in TTBS, blots were placed in a solution of secondary antibody (goat-anti-mouse-immunoglobulin $G$ conjugated to alkaline phosphatase, BioRad Laboratories) consisting of a 1:1000 dilution in TTBS supplemented with $2 \%$ (wt/vol) non-fat dry milk powder for 1 hour. Blots were washed twice in TTBS and once in TBS and immersed in a bicarbonate buffer $\left(\mathrm{NaH}_{2} \mathrm{CO}_{3} 100\right.$ $\mathrm{mmol} / \mathrm{L}, \mathrm{MgCl}_{2} 1 \mathrm{mmol} / \mathrm{L}, \mathrm{pH} 9.8$ ) containing $3 \%$ (wt/vol) p-nitro-blue-tetrazolium chloride p-toluidine salt in $70 \%$ $\mathrm{N}, \mathrm{N}$-dimethyl-formamide and $15 \% \mathrm{wt} / \mathrm{vol}$ 5-bromo-4chloro-3-indolyl phosphate in $100 \% N, N$-dimethyl-formadine. After development, the blot was washed in water and photographed. Bands from immunoblots were quantitated by scanning blots with a Shimadzu CS-9000U densitometer (Shimadzu Scientific Corp., Tokyo, Japan). The values for HSP 72 are presented as a ratio of the levels of HSP 72 found in the human right atrium, compared with the content of HSP 72 found in swine left ventricle. ${ }^{14}$

Fluorography. Gels containing $\left[{ }^{35} \mathrm{~S}\right]$-methionine-labeled proteins were processed for fluorography as described by Bonner and Laskey. ${ }^{15}$ Fluorograms were prepared according to the technique of Laskey and Mills. ${ }^{16}$

Glycogen. Myocardial glycogen concentration was determined with the anthrone reagent as described by Seifter and associates. ${ }^{17}$ In summary, the tissue samples used for glycogen determinations were weighed and quickly immersed in $30 \%$ hot potassium hydroxide until the tissue was completely digested (10 to 30 minutes). The glycogen was precipitated by the addition of $95 \%$ ethanol, followed by heating and cooling. After precipitation, glycogen was diluted in water and a sample reacted with sulfuric acid containing the anthrone reagent. Absorbance was determined spectrophotometrically at $620 \mathrm{~nm}$.

Lactate. The tissue samples used for lactate determination were weighed, placed in cold perchloric acid, 3 $\mathrm{mmol} / \mathrm{L}$, for 15 minutes, and then homogenized and centrifuged. The supernatant was then neutralized with potassium hydroxide, $2 \mathrm{~mol} / \mathrm{L}$, imidazole, $0.4 \mathrm{~mol} / \mathrm{L}$, plus potassium chloride, $0.4 \mathrm{~mol} / \mathrm{L}$, and centrifuged. The supernatant was analyzed for lactate as described by Lowry and Passonneau. ${ }^{18}$ 


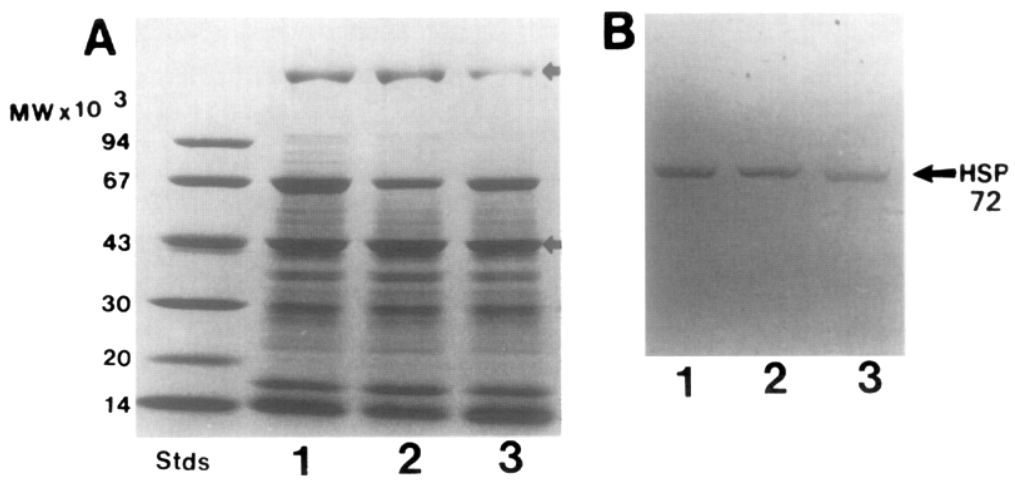

Fig. 2. SDS-PAGE and HSP 72 analyses from the heart of a patient with coronary artery disease. A, The myocardial proteins separated by SDS-PAGE and stained with Coomassie blue. B, A gel identical to that in A, but blotted and reacted with a monoclonal antibody for HSP 72. Both panels: lane 1, before bypass; lane 2, after reperfusion; lane 3, after bypass. $M W$, Molecular weight; Stds, standards.

Statistical analysis. To downweight the possible outlying measurements, whenever feasible the nonparametric approach was adopted in performing statistical analysis. Spearman's rank correlation was computed to reveal the interrelationship between parameters. The Wilcoxon signed-rank test was used to detect differences between prebypass and postreperfusion samples.

\section{Results}

HSP 72 is an inducible protein in human lymphocytes. Fluorographic analysis of the proteins from human lymphocytes separated by IEF/SDS-PAGE (Fig. 1) shows the enhanced synthesis of proteins with molecular weights of $72 \mathrm{kDa}, 73 \mathrm{kDa}$, and 90 $\mathrm{kDa}$ in heat shocked lymphocytes (Fig. 1, $B$ ). These proteins were synthesized at low levels in lymphocytes labeled at $37^{\circ} \mathrm{C}$ (Fig. 1, $A$ ). The $73 \mathrm{kDa}$ and 90 $\mathrm{kDa}$ proteins are the heat shock cognate and the 90 $\mathrm{kDa} \mathrm{HSP}$, respectively. The $72 \mathrm{kDa}$ protein is the inducible member of the HSP 70 family, HSP 72. These results demonstrate that in human lymphocytes, HSP 72 is an inducible protein.

HSP 72 is constitutively expressed in human myocytes. Fig. 2, $A$, demonstrates a Coomassie blue stained gel of the SDS-PAGE separated proteins from human heart muscle before bypass, after reperfusion, and after bypass. Visual inspection of the myosin heavy chain and actin proteins (arrow) demonstrates that wells were loaded with equal amounts of protein. Western blot of the same samples in Fig. 2, $A$, but reacted with antibody for HSP 72, is shown in Fig. 2, $B$.

HSP 72 was detectable in all samples examined. To standardize the HSP 72 content among the various groups in human myocardial samples, human HSP 72 values were compared with the HSP 72 level in swine myocardium. In comparison with the HSP 72 content in swine heart, which is known to be inherently high, prebypass HSP 72 concentration was elevated, $p$ (Binomial) $=0.01$. According to this standardization, HSP 72 content was a mean of $168 \%$ of swine left ventricular content before bypass, $164 \%$ after reperfusion, and $143 \%$ after bypass; therefore, HSP 72 content did not significantly change with the various surgical manipulations, $p(\mathrm{~F}-$ test) $=0.35$.

Similarly, when expressed as percent of (prebypass) control, no significant differences were noted in the mean HSP 72 content ( \pm standard error of the mean) before cardiopulmonary bypass as compared with the mean postreperfusion value $(98.2 \% \pm$ $8.9 \%$ of prebypass control), $p$ (signed-rank) $=0.65$, and the mean postbypass level $(87.6 \% \pm 17.1 \%$ of prebypass control), $p$ (signed-rank) $=0.28$ (Fig. $3, A$ ).

There was no significant correlation among the groups for HSP 72 levels according to age, $p$ (Spear$\operatorname{man})=0.49$, total aortic occlusion time, $p$ (Spear$\operatorname{man})=0.72$, or total cardiopulmonary bypass time, $p($ Spearman $)=0.58$.

Lactate and glycogen. As a marker of metabolic stress in the myocardium, concentrations of lactate and glycogen were investigated. Graphic representation of the values obtained for glycogen and lactate from atrial biopsy tissue before bypass, after reperfusion, and after bypass are shown in Fig. 3, $B$ and $C$. There was no significant difference in the prebypass mean lactate level ( $9.6 \mu \mathrm{mol} / \mathrm{gm}$ of tissue) 

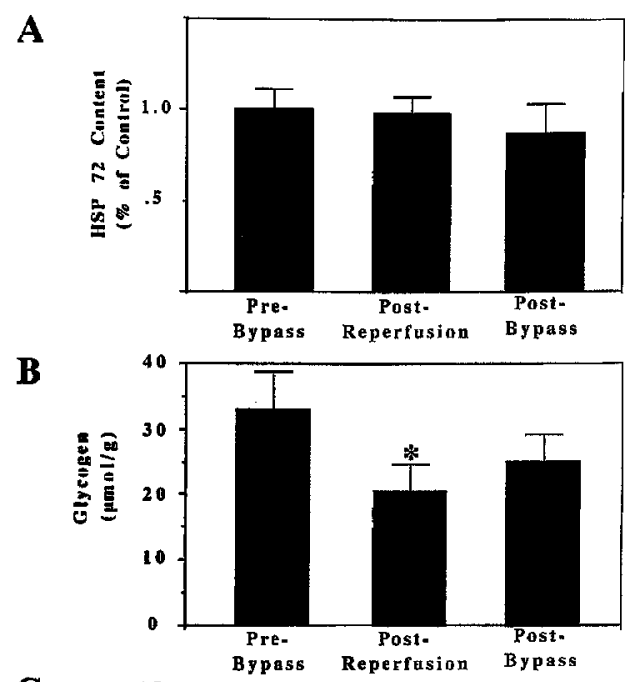

C

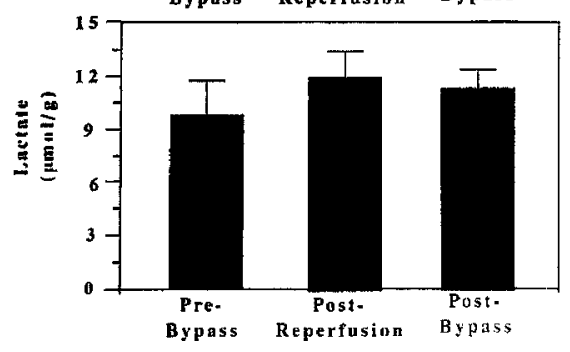

Fig. 3. Graphic representation of HSP 72 content (A), glycogen (B), and lactate (C) concentrations before bypass, after reperfusion, and after bypass.

versus postreperfusion level $(11.9 \mu \mathrm{mol} / \mathrm{gm}$, $p[$ signed-rank $]=0.14)$, and postbypass level $(11.3$ $\mu \mathrm{mol} / \mathrm{gm}, p$ [signed-rank] $=0.06$ ).

A change in the glycogen content was observed between prebypass and postreperfusion values: mean prebypass glycogen level $=33.0 \mu \mathrm{mol} / \mathrm{gm}$ of tissue, postreperfusion $=20.7 \mu \mathrm{mol} / \mathrm{gm}, p$ (signedrank) $=0.02$, and postbypass $=25.0 \mu \mathrm{mol} / \mathrm{gm}$, $p$ (signed-rank) $=0.41$.

\section{Discussion}

Although various pharmacologic therapies have been investigated to determine their efficacy in enhancing tissue survival after episodes of myocardial ischemia, none has been absolutely shown to have the ability to reduce infarct size in animal models. The induction of the HSPs, which have been shown to be associated with cardiac protection in isolated heart models, have been demonstrated to reduce infarct size and delay the onset of irreversible myocardial ischemic injury. ${ }^{19}$ Five major groups of HSPs have been identified: the low-molecularweight 22 to $30 \mathrm{kDa}$ stress proteins, the 50 to $60 \mathrm{kDa}$ stress proteins, the $70 \mathrm{kDa}$ stress proteins, the 90 $\mathrm{kDa}$ stress proteins, and the high-molecular-weight $110 \mathrm{kDa}$ stress proteins.

The HSP $70 \mathrm{kDa}$ family consists of at least four isoforms. ${ }^{20}$ Two isoforms are induced by glucose deprivation and thus termed glucose-regulated proteins. Glucose-regulated protein 75 is present in the mitochondria, and glucose-regulated protein 78 is present in the sarcoplasmic reticulum. ${ }^{21} \mathrm{~A}$ third isoform, the heat shock cognate, termed HSC 73, is a cytoplasmic protein expressed in cells during unstressed conditions. ${ }^{22}$ The HSP 72 isoform is generally a stress-inducible isoform that is absent during unstressed conditions but rapidly synthesized during or after episodes of stress. ${ }^{23}$ A variety of proteotoxic (protein damaging) agents including ischemia, heat, ethanol, heavy metals, hypoxia, amino acid analogs, metabolic inhibitors, and denatured proteins have been shown to induce HSP 72 synthesis. ${ }^{24}$ The novel aspect of this study is the detection of a relatively high HSP 72 content in the human heart and the lack of an increased HSP 72 content during surgery.

The lack of an observed increase in HSP 72 content in this study after the period of ischemia and the various surgical interventions may be related to several factors. First, the already high level of HSP 72 expressed may have been sufficient for the ischemic episode incurred. Second, the high constitutive HSP 72 content may have inhibited HSP 72 transcription, because HSP 72 has been shown to inhibit additional HSP 72 transcription by binding to the heat shock transcription factor. ${ }^{25}$ Third, because the surgical procedures performed in this study were of a short duration (less than 2 hours), the time required to detect HSP 72 accumulation may have been insufficient. For example, in animals, although HSP 72 messenger ribonucleic acid has been shown to be rapidly induced ( 5 minutes in canine hearts after ischemia), the HSP 72 protein rises to peak levels 8 to 24 hours after the stress. ${ }^{26}$ Last, because the only significant metabolic change was in glycogen content between prebypass and postreperfusion measurements, the metabolic stresses to the heart during the operation may not have been severe enough to significantly elevate HSP 72 content.

HSP 72 has been shown to confer thermo-tolerance to cultured cells, such that cells with an increased HSP 72 content can withstand normally lethal temperatures. ${ }^{27-29}$ Although the exact function of HSP 72 remains unknown, it is thought that HSP 72 may protect cells from stressors by helping restore denatured proteins to their original 
shape. ${ }^{20,30}$. Because HSP 72 has been shown to protect cells from stresses, it remains probable that HSP 72 may provide a protective effect to cardiomyocytes. In support of this, Currie and Tanguay ${ }^{31}$ have demonstrated that rats subjected to pretreatment with whole-body hyperthermia have higher HSP 72 levels with resultant cardiac protection from ischemia. Karmazyn, Mailer, and Currie $^{32}$ have demonstrated that 24 hours after rats were subjected to whole-body hyperthermia and the induction of HSP 72, a faster recovery of force, rate of contraction, rate of relaxation, and a decreased release of creatine kinase was observed in hearts from heat-shocked rats compared with hearts from non-heat-shocked animals. More recently, Currie, Tanguay, and Kingma ${ }^{33}$ have demonstrated that heat shock, and the subsequent increase in HSP 72, decreased infarct size in rabbits. Thus preconditioning the heart to contain a high amount of HSP 72 seems to allow the heart to endure ischemia-reperfusion episodes.

Whether the high HSP 72 level expressed in the hearts of these patients is related to their preexistent pathologic conditions and pharmacologic intervention, or simply reflects an inherently high expression of HSP 72, cannot be determined from the present study. However, it seems probable that HSP 72 is constitutively expressed at high levels in the normal human heart, because the unstressed swine heart also expresses a high level of HSP $72 .{ }^{14}$ Thus HSP 72 may be required in human myocytes because it serves a function(s) that is specific but distinct from the general stress-related functions of HSP 72 in stressed cells, or because human myocytes are subjected to a stressful environment and require HSP 72 for certain stress-related functions.

The detection of a high constitutive expression of HSP 72 raises some interesting questions. First, why is this normally stress-inducible protein present in the heart in such high quantities? Second, does the high level of HSP 72 expression noted in this study imply that preconditioning, with the goal of increasing preoperative HSP 72 content, is futile or unnecessary? The answers remain unknown. However, from our findings it seems that because the HSP 72 levels are inherently high in these patients at the time of operation, whatever protective benefit that might be derived from this protein may already be occurring. Although HSP 72 content remained unchanged during the operations in this study, it remains possible that the role or function of HSP 72 may have changed. In unstressed cells HSP 72 is initially located in the cytoplasm, but after exposure to stress HSP 72 moves to the nucleus. ${ }^{34}$ Thus, although HSP 72 content remained unchanged after operation in this study, cellular location before and after bypass may have changed. Whether the intracellular location of HSP 72 in cardiomyocytes changes during surgery also remains to be determined. Further analysis of these processes is essential to our understanding of the role of HSP 72 in cardiac tissue.

In summary, HSP 72 content was unchanged in atrial biopsy tissue before bypass, after reperfusion, and after bypass. A high HSP 72 content was observed in the human heart in comparison with the HSP 72 content in the swine heart. Although the exact reason for the hearts of these patients expressing HSP 72, a stress-inducible protein in most cells, remains unknown, it may reflect preoperative disease or simply a high constitutive HSP 72 expression.

We acknowledge the technical assistance of Patricia Finkbinder, Maggie Feild, and Sigrid Ianuzzo and the work on the manuscript by Nancy Couitt and Jeanne Harrison.

\section{REFERENCES}

1. Roberts AJ. Perioperative myocardial infarction: changes in left ventricular performance related to coronary artery bypass graft surgery (collective review). Ann Thorac Surg 1983;35:208-25.

2. McGoon DC. The ongoing quest for ideal myocardial protection: a catalogue of the recent English literature. J Thorac CardiovasC SuRg 1985;89:639-53.

3. Buckberg GD. Strategies and logic of cardioplegic delivery to prevent, avoid, and reverse ischemic and reperfusion damage. J THORAC CARdiovasc SuRG 1987;93:127-39.

4. Lazar HL, Buckberg GD, Manganaro AM, Becker H. Myocardial energy replenishment and reversal of ischemic damage by substrate enhancement of secondary blood cardioplegia with amino acids during reperfusion. J Thorac Cardiovasc Surg 1980;80: 350-9.

5. Salerno TA, Houck JP, Barrozo CAM, et al. Retrograde continuous warm blood cardioplegia: a new concept in myocardial protection. Ann Thorac Surg 1991;51:254-7.

6. Conti VR, Bertranou EG, Blackstone EH, Kirklin JW, Digerness JW. Cold cardioplegia versus hypothermia for myocardial protection. J THORAC CARDIOVASC SURG 1978;76:577-89.

7. Knowlton AA, Brecher P, Apstein CS. Rapid expression of heat shock protein in the rabbit after brief cardiac ischemia. J Clin Invest 1991;87:139-47. 
8. Donnelly TJ, Sievers RE, Vissern FLJ, Welch WJ, Wolfe CL. Heat-shock protein induction in rat hearts: a role for improved myocardial salvage after ischemia and reperfusion? Circulation 1992;85:769-78.

9. Currie RW, Karmazyn M, Kloc M, Mailer K. Heatshock response is associated with enhanced postischemic ventricular recovery. Circ Res 1988;63:543-9.

10. Lowry $\mathrm{OH}$, Rosebrough NJ, Farr AL, Randall RJ. Protein measurements with the folin phenol reagent. J Biol Chem 1951;193:265-75.

11. Laemmli UK. Cleavage of structural proteins during the assembly of the head of bacteriophage T4. Nature (London) 1970;227:680-5.

12. O'Farrell PH. High resolution two dimensional electrophoresis of proteins. J Biol Chem 1975;250:400721.

13. Tobin H, Staehelin T, Gordon J. Electrophoretic transfer from polyacrylamide gels to nitrocellulose sheets: procedure and some applications. Proc Natl Acad Sci U S A 1979;76:4350-4.

14. Locke M, Feild MR, Ianuzzo SE, Ianuzzo CD. HSP 72 expression in different sized mammalian hearts [Abstract]. J Mol Cell Cardiol 1993;25(Suppl III):S28.

15. Bonner WM, Laskey RA. A film detection method for tritium-labelled proteins and nucleic acids in polyacrylamide gels. Eur J Biochem 1974;46:83-8.

16. Laskey RA, Mills AD. Quantitative film detection of ${ }^{3} \mathrm{H}$ and ${ }^{14} \mathrm{C}$ in polyacrylamide gels by fluorography. Eur J Biochem 1975;56:335-41.

17. Seifter S, Dayton S, Novic B, Muntwyler E. The estimation of glycogen with anthrone reagent. Arch Biochem 1950;25:191-200.

18. Lowry $\mathrm{OH}$, Passonneau JV. A collection of metabolite assays. In: Lowry $\mathrm{OH}$, Passoneau JV, eds. A flexible system of enzymatic analysis. 1st ed. New York: Academic Press, 1972:199-201.

19. Yellon DM, Latchman DS, Marber MS. Stress proteins-an endogenous route to myocardial protection: Fact or fiction? Cardiovasc Res 1993;27:158-61.

20. Pelham HRB. Speculations of the functions of the major heat shock and glucose regulated proteins. Cell 1986;46:959-61.

21. Munro S, Pelham HRB. An Hsp70-like protein in the ER: identity with the $78 \mathrm{kd}$ glucose-regulated protein and immunoglobulin heavy chain binding protein. Cell 1986;46:291-300.

22. Sorger PK, Pelham HRB. Cloning and expression of a gene encoding hsc73, the major hsp70-like protein in unstressed rat cells. EMBO J 1987;6:993-8.

23. Milarski KL, Morimoto RI. Mutational analysis of the human HSP70 protein: distinct domains for nucleolar localization and adenosine triphosphate binding. $\mathbf{J}$ Cell Biol 1989;109:1947-62.

24. Morimoto RI, Tissieres A, Georgopoulos C, eds. Stress proteins in biology and medicine. Cold Spring Harbor, N.Y. Cold Spring Harbor Laboratory Press, 1990.

25. Abravaya K, Myers MP, Murphy SP, Morimoto RI. The human heat shock protein hsp70 interacts with HSF, the transcription factor that regulates heat shock gene expression. Genes Dev 1992;6:1153-64.

26. Mehta HB, Popovich BK, Dillmann WH. Ischemia induces changes in the level of mRNAs coding for stress protein 71 and creatine kinase. J Circ Res 1988;63:512-7.

27. Angelidis CE, Lazaridis I, Pagoulatos GN. Constitutive expression of heat-shock protein-70 in mammalian cells confers thermoresistance. Eur J Biochem 1991;199:35-9.

28. Li GC, Li LG, Liu YK, Mak JY, Chen LL, Lee WM. Thermal response of rat fibroblasts stably transfected with the human $70-\mathrm{kDa}$ heat shock protein-encoding gene. Proc Natl Acad Sci U S A 1991;88:1681-5.

29. Li GC, Li L, Liu RY, Rehman M, Lee WF. Heat shock protein hsp70 protects cells from thermal stress even after deletion of its ATP binding site. Proc Natl Acad Sci U S A 1992;89:2036-40.

30. Beckmann RP, Mizzen LA, Welch WJ. Interaction of hsp70 with newly synthesized proteins: implications for protein folding and assembly. Science 1990;248: $850-4$.

31. Currie RW, Tanguay RM. Analysis of RNA for transcripts for catalase and SP71 in rat hearts after in vivo hyperthermia. Biochem Cell Biol 1991;69:375-82.

32. Karmazyn M, Mailer K, Currie WR. Acquisition and decay of heat-shock-enhanced postischemic ventricular recovery. Am J Physiol 1990;259:H424-31.

33. Currie RW, Tanguay RM, Kingma JG Jr. Heat-shock response and limitation of tissue necrosis during occlusion/reperfusion in rabbit hearts. Circulation 1993;87:963-71.

34. Lewis MJ, Pelham HRB. Involvement of ATP in the nuclear functions of the $70 \mathrm{kd}$ heat shock protein. EMBO J 1985;4:3137-43. 